\title{
Early Gonadogenesis and Sex Differentiation in the Korean Rose Bitterling, Rhodeus uyekii
}

\author{
In Bon Goo ${ }^{1}$, Jung Eun Kim ${ }^{1}$, Myung Hun Kim ${ }^{1}$, Hye-Sung Choi ${ }^{1}$, Hee Jeong Kong ${ }^{2}$, \\ Jeong Ho Lee ${ }^{1}$ and ${ }^{\dagger}$ In-Seok Park ${ }^{3}$ \\ ${ }^{1}$ Inland Aquaculture Research Center, National Institute of Fisheries Science (NIFS), Changwon 51688, Korea \\ ${ }^{2}$ Biotechnology Research Division, NIFS, Busan 46083, Korea \\ ${ }^{3}$ Division of Marine Bioscience, Korea Maritime and Ocean University, Busan 49112, Korea
}

\begin{abstract}
This report describes the sex differentiation of the Korean rose bitterling, Rhodeus uyekii, from hatching to 170 days post-hatch (DPH) in relation to total length (TL), body weight (BW), and integral water temperature (IWT). The growth curve of TL from just hatching to $83 \mathrm{DPH}$ was $5.144 \mathrm{e}^{0.045 \mathrm{t}}\left(R^{2}=0.961\right.$; $\mathrm{t}$, time $)$, and that of $\mathrm{BW}$ was $2.398 \mathrm{e}^{0.086 \mathrm{t}}\left(R^{2}=\right.$ 0.725). Primordial germ cells (PGCs) were observed at $17 \mathrm{DPH}\left(7.9 \mathrm{~mm}\right.$ TL, $3.74 \mathrm{mg} \mathrm{BW}, 374^{\circ} \mathrm{C}$ IWT), and thereafter began to protrude into the peritoneal cavity. At $21 \mathrm{DPH}\left(9.2 \pm 0.14 \mathrm{~mm} \mathrm{TL}, 4.8 \pm 0.07 \mathrm{mg} \mathrm{BW}, 462^{\circ} \mathrm{C}\right.$ IWT), some PGCs contained condensed chromatin and oocyte were observed in meiotic prophase. In contrast to the ovaries, which grew gradually after sexual differentiation, testes began multiplying at $25 \mathrm{DPH}\left(10.1 \mathrm{~mm} \mathrm{TL}, 5.42 \mathrm{mg} \mathrm{BW}, 550^{\circ} \mathrm{C}\right.$ IWT), when testicular differentiation was first identified, and multiplied continuously thereafter. At $33 \mathrm{DPH}\left(11.2 \mathrm{~mm} \mathrm{TL}, 10.5 \mathrm{mg} \mathrm{BW}, 726^{\circ} \mathrm{C}\right.$ IWT), the developing testes contained spermatogonia that exhibited mitotic activity. No spermatocyte or sperm cell was observed until $83 \mathrm{DPH}\left(18.9 \mathrm{TL}, 48.2 \mathrm{mg} \mathrm{BW}, 1,826^{\circ} \mathrm{C}\right.$ IWT). At $170 \mathrm{DPH}\left(32.5 \mathrm{~mm} \mathrm{TL}, 270.1 \mathrm{mg} \mathrm{BW}, 3,740^{\circ} \mathrm{C} \mathrm{IWT}\right)$, which was the end point of this study, the mature ovaries showed germinal vesicle breakdown, while the mature testes contained observable spermatocytes and sperm cells. These results allow us to identify the sex differentiation type of the Korean rose bitterling as differentiated gonochoristic.
\end{abstract}

Key words : Early growth, Gonadogenesis, Rhodeus uyekii, Sex differentiation

\section{INTRODUCTION}

In teleosts, the sex differentiation pattern may be classified as synchronous hermaphroditism (protandrous and protogynous) or gonochorism (undifferentiated and differrentiated) (Yamamoto, 1969). Both genetic and environmental factors can significantly impact the sex determination of fish (Devlin \& Nagahama, 2002). The physico- chemical factors relevant to the sex determination of fish include the water temperature, salinity, and $\mathrm{pH}$ (Baroiller et al., 1999), while the related chemical factors include polychorinated biphenyls (PSBs), nonylphenol, bisphenol, and dioxin by endocrine disruptor (Gray \& Metcalf, 1997). To improve the economics of aquaculture, these parameters may be used to render fish populations artificially mono-sexual (e.g., by adjusting the water temperature,

\footnotetext{
Manuscript received October 18, 2016, Received in revised form November 16, 2016, Accepted December 9, 2016

${ }^{\dagger}$ Corresponding Author : In-Seok Park, Division of Marine Bioscience, College of Ocean Science and Technology, Korea Maritime and Ocean University, Busan 606-791, Korea. Tel: +82-51-410-4321, Fax: +82-51-405-4322, E-mail: ispark@kmou.ac.kr

This is an Open Access article distributed under the terms of the Creative Commons Attribution Non-Commercial License (http:// creativecommons.org/licenses/by-nc/3.0) which permits unrestricted non-commercial use, distribution, and reproduction in any medium, provided the original work is properly cited.
} 
controlling the $\mathrm{pH}$, or applying hormone treatments).

The Korean rose bitterling, Rhodeus uyekii, is an indigenous species in Korea. Falling within the Cypriniformes, Cyprinidae, and Rhodeus, these fish live on the muddy floor at the edges of reservoirs, plant-filled and/or slowmoving streams, and ponds. They are distributed in the watershed of the Nakdong River and other streams in the Southern part of Korea (Jeon, 1982). The Korean rose bitterling breeds between the end of April and mid-June, and shows special features in breeding in the fresh water bivalves of the Family Unionidae by extending the ovipositor in the female (Uchida, 1939; Nakamura, 1969). Seen from the side, the body of the Korean rose bitterling is relatively compressed from nose to tail and relatively tall from the caudal to dorsal aspect, with the male generally being taller than the female. In color, the body is light brown on the back, darker on the front back of the dorsal fin and the caudal peduncle, and reddish white silver on the flank. The male is black on the outside of its rear fin and exhibits a small white spot inside. The female has black of its rear fin as only patterning. Given its excellent visual effect, the male is far preferred over the female as an aquarium fish, besides the taxonomic group with urgent preservation due to easy exposure to the recent biological and environmental pollution (Kang et al., 2006).

For the Korean rose bitterling, researchers have studied: the early life history of laboratory-reared fish; egg and larval development; the seasonal sex ratio in the field; the reproductive cycle of the spring-spawning bitterling; osteology; elongation of the ovipositor; the temperaturedependent index of the mitotic interval $\left(\tau_{0}\right)$ for chromosome manipulation; morphometric traits; cytogenetics of induced crosses and reciprocal hybrids between Korean rose bitterling and $R$. notatus; and the use of lidocaine hydrochloride and clove oil as an anesthetic (for both Korean rose bitterling and oily bitterling, Acheilognathus koreensis) (Kim \& Han, 1990; Park \& Kim, 1990; An, 1995;
Kim, 1997; Chae, 2001; Kim et al., 2011, 2012). Studies have also examined trends in the early development of the gonad and the potential for sex change, but the process of sex differentiation in the Korean rose bitterling is not yet fully understood.

Here, we investigated the sex differentiation and gonadal development of the Korean rose bitterling, and their dependence on the initial growth and integral water temperature at the constant breeding water temperature for the hatching fry through the artificial insemination as a part of production of the monosexual population and the seed production of the Korean rose bitterling.

\section{MATERIALS AND METHODS}

\section{Experimental fish}

Brood stock of the Korean rose bitterling, Rhodeus uyekii, were obtained from the Inland Aquaculture Research Center, National Institute of Fisheries Science (NIFS; Changwon, Korea) and housed in a mariculture facility at the Fishery Genetics and Breeding Sciences Laboratory of the Korea Maritime and Ocean University in Busan, Korea. The fish were maintained in a glass tank $($ W $120 \mathrm{~cm} \times \mathrm{L}$ $30 \mathrm{~cm} \times \mathrm{H} 50 \mathrm{~cm})$ at a water temperature of $20 \pm 1^{\circ} \mathrm{C}$ until the experiments were initiated.

\section{Artificial spawning and hatching}

During the 2013 spawning season (late April to midJune), densely colored males and ovipositor-extended females were selected and used as brood stock. Eggs were harvested by abdominal compression of ovipositor-extended females, semen was harvested by abdominal compression of males and inseminated within 2 minutes. Plastic tanks (W $30 \mathrm{~cm} \times$ L $20 \mathrm{~cm} \times$ H $15 \mathrm{~cm}$; Fresh Plus, Mirae Chemical, Korea) were loaded with 200 eggs each and maintained at a water depth of $10 \mathrm{~cm}$ and a L:D ratio of 13:11 until hatching. The water was replaced twice daily with 
aerated bottled water (Natural Mineral Water, Pulmuone, Korea), and the water temperature was maintained at $22 \pm 0.5^{\circ} \mathrm{C}$.

\section{Rearing conditions}

Hatched larvae were divided into groups of 10 and distributed to transparent plastic containers (W $10 \mathrm{~cm} \times \mathrm{L} 5$ $\mathrm{cm} \times \mathrm{H} 3 \mathrm{~cm}$; Coolrara, Easyfilm, Korea). The other conditions were as described in the "Artificial spawning and hatching" section above. Each day, the average water temperature and integral water temperature were recorded. The larvae began to feed once the yolk was completely absorbed, at 21 days post-hatching (DPH).

\section{Specimens and histological observation of gonads}

The hatchlings $(n=20)$ were sampled daily from hatching to $5 \mathrm{DPH}$, at 2-day intervals from 7 to $21 \mathrm{DPH}$, at 4day intervals from 25 to $41 \mathrm{DPH}$, at 6-day intervals from 47 to $83 \mathrm{DPH}$, and at 30-day intervals from 110 to 170 DPH. The fish were sampled at different stages and anesthetized with $300 \mathrm{ppm}$ lidocaine- $\mathrm{HCl} / \mathrm{NaHCO}_{3}$ at $25^{\circ} \mathrm{C}$ according to method of Kang et al. (2005). Body weight (BW) was measured to the nearest $0.01 \mathrm{~g}$ using an electric balance (AX 200, Shimadzu Corp., Japan), the total length (TL) was measured to the nearest $0.01 \mathrm{~cm}$ using a vernier caliper (CD-20 CP, Mitutoyo, Japan), and growth was estimated using an exponential growth curve and the calculation of a condition factor.

A mimetic diagram was produced according to the growth for indicate morphological changes. Each sample of whole fish was fixed in Bouin's solution for $24 \mathrm{~h}$, washed thoroughly with water, exposed to decalcification solution for $24 \mathrm{~h}$, washed again, and dehydrated through a graded alcohol series $(70 \%, 80 \%, 90 \%$, and $100 \%$ ethanol $1 \mathrm{~h}$ each). The samples were then cleared with xylene, impregnated with soft paraffin, impregnated with hard paraffin, embedded, trimmed, and cut $(6 \mu \mathrm{m})$. The sections were placed on slides, stained with hematoxylin-eosin, mounted with Canadian balsam, and examined/photographed under optical microscopy (AxioCam MR, Carl Zeiss, Germany).

\section{RESULTS}

The Korean rose bitterling, Rhodeus uyekii, hatched at two days post-fertilization with a post-fertilization integral water temperature (IWT) of $43^{\circ} \mathrm{C}$. Fig. 1, Fig. 2 , and 3 present the changes in total length (TL), body weight (BW), condition factor, and morphology from just-hatched (IWT post-hatching $0^{\circ} \mathrm{C}$ ) to 170 days post-hatching (DPH; IWT post-hatching $3,740^{\circ} \mathrm{C}$ ). At hatching, the average $\mathrm{TL}$ and BW were $6.1 \pm 0.09$ (SD) $\mathrm{mm}$ and $4.9 \pm 0.07 \mathrm{mg}$, respectively, while at $83 \mathrm{DPH}$, these values were $18.9 \pm 0.28 \mathrm{~mm}$ and $48.2 \pm 0.72 \mathrm{mg}$, respectively (Fig. 1 and Fig. 3). TL in-
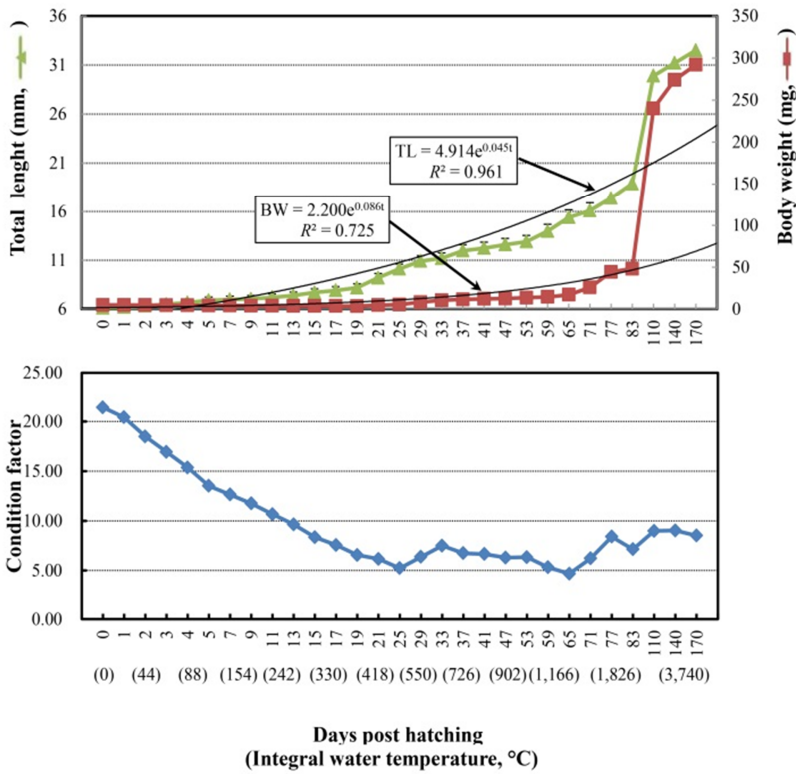

Fig. 1. Total length and body weight growth curves (upper) and condition factor (lower) of the Korean rose bitterling, Rhodeus uyekii, from hatching to 170 days post-hatch. The results are presented as the means \pm SD of triplicate groups. Vertical bars represent standard deviations. Abbreviations: TL, total length; BW, body weight; and $\mathrm{t}$, time. Condition factor $=\left(a / b^{3}\right) \times 1,000$ where $a$ is BW and $b$ is TL. 
A

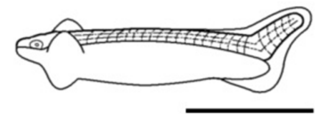

B

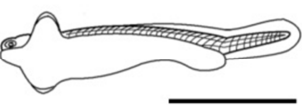

C

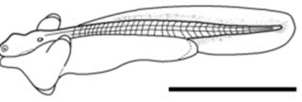

D

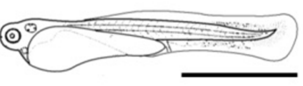

E

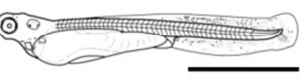

F

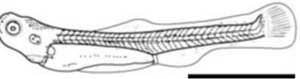

G

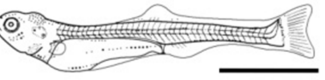

$\mathbf{H}$

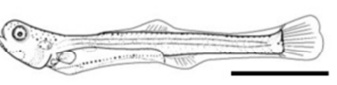

I

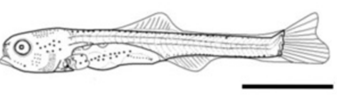

$\mathbf{J}$

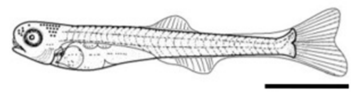

K

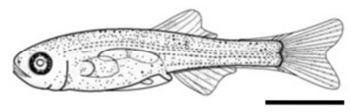

$\mathbf{L}$

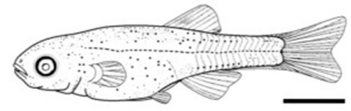

Fig. 2. Development of the Korean rose bitterling, Rhodeus uyekii. A: At $1 \mathrm{DPH}, 6.1 \pm 0.09 \mathrm{~mm} \mathrm{TL}, 22^{\circ} \mathrm{C}$ IWT. B: At $2 \mathrm{DPH}, 6.2 \pm 0.09 \mathrm{~mm}$ TL, $44^{\circ} \mathrm{C}$ IWT. C: At $3 \mathrm{DPH}, 6.5 \pm 0.10 \mathrm{~mm}$ TL, $66^{\circ} \mathrm{C}$ IWT. D: At 7 $\mathrm{DPH}, 6.9 \pm 0.10 \mathrm{~mm} \mathrm{TL}, 154^{\circ} \mathrm{C}$ IWT. E: At $9 \mathrm{DPH}$, $7.0 \pm 0.11 \mathrm{~mm} \mathrm{TL}, 198^{\circ} \mathrm{C}$ IWT. F: At $11 \mathrm{DPH}, 7.2$ $\pm 0.11 \mathrm{~mm} \mathrm{TL}, 242^{\circ} \mathrm{C}$ IWT. G: At $17 \mathrm{DPH}, 7.9 \pm$ $0.12 \mathrm{~mm} \mathrm{TL}, 374^{\circ} \mathrm{C}$ IWT. H: At $19 \mathrm{DPH}, 8.2 \pm 0.12$ $\mathrm{mm} \mathrm{TL}, 418^{\circ} \mathrm{C}$ IWT. I: At $21 \mathrm{DPH}, 9.2 \pm 0.14 \mathrm{~mm}$ TL, $462^{\circ} \mathrm{C}$ IWT. J: At $25 \mathrm{DPH}, 10.1 \pm 0.15 \mathrm{~mm}$ TL, $550^{\circ} \mathrm{C}$ IWT. K: At $33 \mathrm{DPH}, 11.2 \pm 0.17 \mathrm{~mm} \mathrm{TL}$, $726^{\circ} \mathrm{C}$ IWT. L: At $53 \mathrm{DPH}, 12.9 \pm 0.19 \mathrm{~mm} \mathrm{TL}$, $1,166^{\circ} \mathrm{C}$ IWT. Bars $=3 \mathrm{~mm}$.

creased continuously from hatching to $83 \mathrm{DPH}$, and could be represented by the growth equation: $\mathrm{TL}=4.914 \mathrm{e}^{0.045 \mathrm{t}}\left(R^{2}\right.$ $=0.961 ; \mathrm{t}$, time) (Fig. 1, upper panel). BW showed a slight reduction between hatching and the completion of yolk absorption (21 DPH, see below), but increased rapidly once the hatchling began to feed; it could be represented by the growth equation: $\mathrm{BW}=2.200 \mathrm{e}^{0.086 \mathrm{t}}\left(R^{2}=0.725\right)$ (Fig. 1). The condition factor decreased from just-hatching to 21 DPH, but remained steady thereafter (Fig. 1, lower panel, and Fig. 2-I). Yolk absorption was complete at $21 \mathrm{DPH}$ $\left(9.2 \pm 0.14 \mathrm{~mm}\right.$ TL, $4.8 \pm 0.07 \mathrm{mg} \mathrm{BW} ; 462^{\circ} \mathrm{C}$ IWT post hatching) (Fig. 2-I). At that point, the hatchling exhibited the

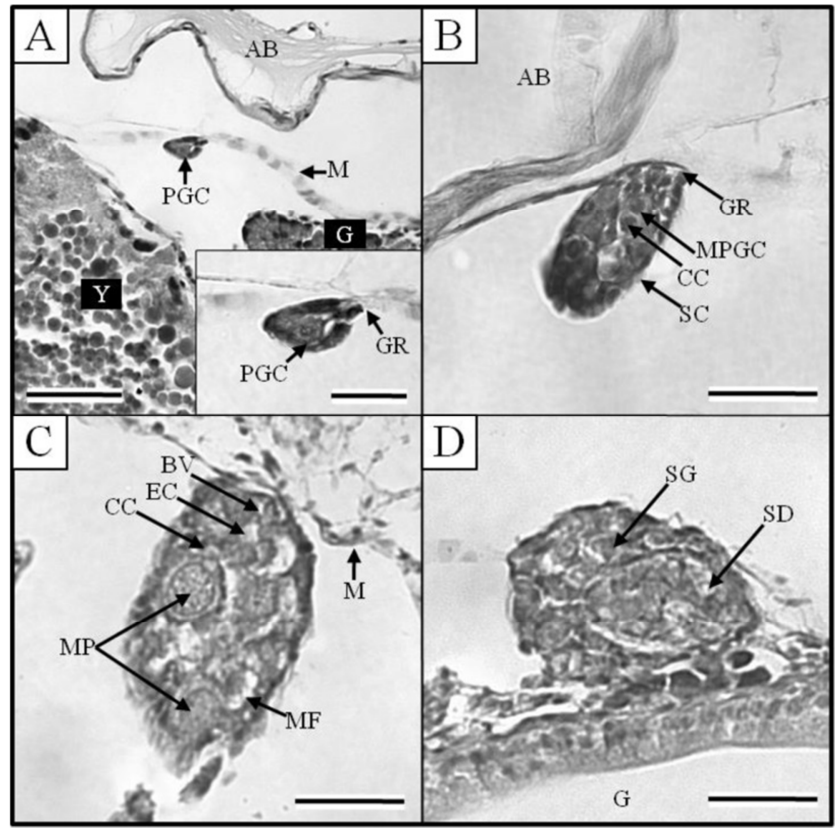

Fig. 3. Histological analysis of gonadogenesis in the Korean rose bitterling, Rhodeus uyekii. A: At 17 $\mathrm{DPH}, 374^{\circ} \mathrm{C}$ IWT; inset shows a high-power view of a primordial germ cell (PGC; inset bar $=10 \mu \mathrm{m})$. B: At $19 \mathrm{DPH}, 418^{\circ} \mathrm{C}$ IWT, undifferentiated gonads. C: At $21 \mathrm{DPH}, 462^{\circ} \mathrm{C}$ IWT, ovary. D: At $25 \mathrm{DPH}$, $550^{\circ} \mathrm{C}$ IWT, testis. Abbreviations: AB, air bladder; $\mathrm{CC}$, condensed chromatin; EC, endoovarian canal; $\mathrm{G}$, gut; GR, genital ridge; $\mathrm{M}$, mesentery; $\mathrm{MF}$, meiotic figure; MP, meiotic prophase; MPGC, mitotic primordial germ cell; PGC, primordial germ cell; $\mathrm{SC}$, somatic cell; SD, sperm duct; SG, spermatogonia; and Y, yolk. H \& E staining. Bars $=20 \mu \mathrm{m}$.

larval form.

At $17 \mathrm{DPH}\left(7.9 \pm 0.12 \mathrm{~mm} \mathrm{TL}, 3.7 \pm 0.06 \mathrm{mg} \mathrm{BW}, 374{ }^{\circ} \mathrm{C}\right.$ IWT) (Fig. 2-G) when the first feeding commenced following complete absorption of the yolk, gonads became apparent on both sides, running beneath the air bladder mesentery to the genital ridge in the abdominal cavity (Fig. 3A). The primordial germ cells (PGCs) were oval, approximately $7.2 \mu \mathrm{m}$ in diameter, and enclosed by loose connective tissue. Their cytoplasm was weakly stained by hematoxylin, and they contained round nuclei of $2 \mu \mathrm{m}$ in diameter (Fig. 3A insert). By 19 DPH (8.2 $\pm 0.12 \mathrm{~mm}$ TL, 
3.6 $\pm 0.05 \mathrm{mg} \mathrm{BW}, 418^{\circ} \mathrm{C}$ IWT) (Fig. 2-H) the number of PGCs was increased and numerous mitotic PGCs and condensed chromatin were apparent (Fig. 3B).

At $21 \mathrm{DPH}$ (Fig. 2-I: $9.2 \pm 0.14 \mathrm{~mm}$ TL, $4.8 \pm 0.07 \mathrm{mg}$ $\mathrm{BW}, 462^{\circ} \mathrm{C}$ IWT), some of the PGCs contained condensed chromatin; oocytes were observed in meiotic prophase; and the PGCs and oocytes were enclosed by somatic cells

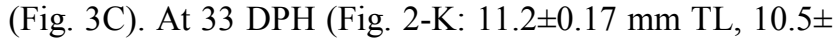
$0.16 \mathrm{mg} \mathrm{BW}, 726^{\circ} \mathrm{C}$ IWT), numerous oocytes were observed in meiotic prophase, meiotic figures were present, and the oocytes were in the chromatin-nucleolus stage, with blood vessels and endo-ovarian canals beginning to fill the ovary (Fig. 3C). At 53 DPH (Fig. 2-L: 12.9 $\pm 0.19 \mathrm{~mm}$ TL, $13.6 \pm 0.20 \mathrm{mg} \mathrm{BW}, 1,166^{\circ} \mathrm{C}$ IWT), the oocytes were in the perinucleolus stage and had increased to $50 \mu \mathrm{m}$ in diameter (Fig. 4A). Perinucleolus-stage oocytes increased in number and size to $83 \mathrm{DPH}$. From 110 to $170 \mathrm{DPH}$, mature oocytes exhibited germinal vesicle breakdown (Fig. 4C).

The Korean rose bitterling appeared to begin its sex differentiation when yolk absorption was completed and the first feeding began (21 DPH). At 25 DPH (Fig. 2-J: $10.1 \pm 0.15 \mathrm{~mm} \mathrm{TL}, 5.4 \pm 0.08 \mathrm{mg} \mathrm{BW}, 550^{\circ} \mathrm{C}$ IWT), spermatogonia could be distinguished from PGCs (Fig. 3D). At 33 DPH (Fig. 2-K: $11.2 \pm 0.17 \mathrm{~mm}$ TL, $10.5 \pm 0.16 \mathrm{mg} \mathrm{BW}$, $726^{\circ} \mathrm{C}$ IWT), the spermatogonia had increased in number (Fig. 4B). No significant development of the testes was seen up to $83 \mathrm{DPH}$ (18.9 mm TL, $48.2 \mathrm{mg} \mathrm{BW}, 1,826^{\circ} \mathrm{C}$ IWT).

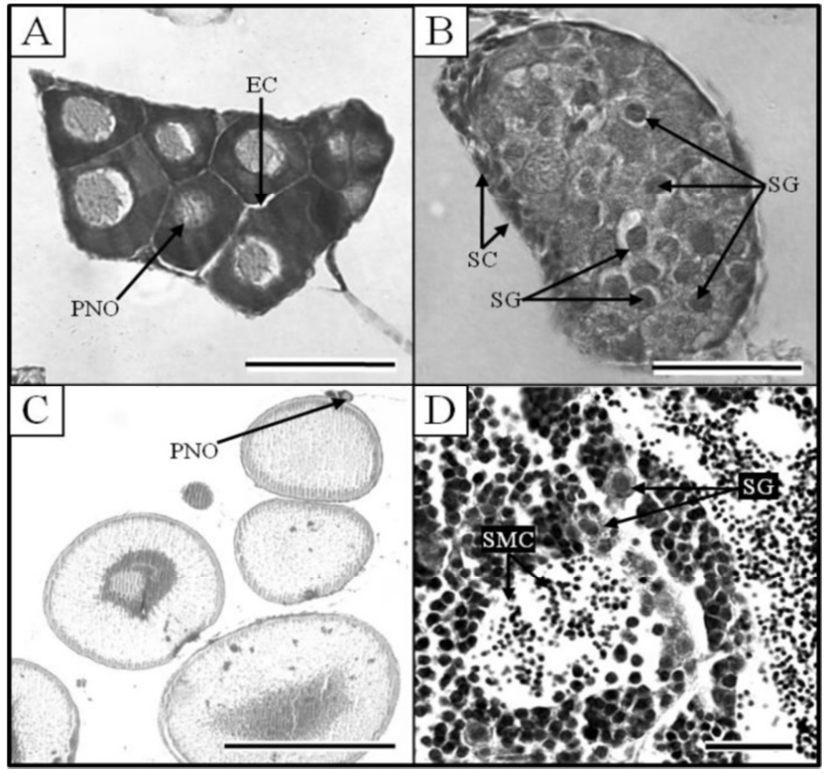

Fig. 4. Histological analysis of gonadogenesis in the Korean rose bitterling, Rhodeus uyekii. A: At 53 DPH, $1,166^{\circ} \mathrm{C}$ IWT, ovary. B: At 53 DPH, $1,166^{\circ} \mathrm{C}$ IWT, testis. C: At $170 \mathrm{DPH}, 3,740^{\circ} \mathrm{C}$ IWT, ovary. D: At $170 \mathrm{DPH}, 3,740^{\circ} \mathrm{C}$ IWT, testis. Abbreviations: $\mathrm{EC}$, endoovarian canal; $\mathrm{PNO}$, oocyte in the perinucleolus stage; SC, somatic cell; SG, spermatogonia; SMC, spermatocyte. H \& E staining. Bars: in $\mathrm{A}$ and $\mathrm{B}=30 \mu \mathrm{m}$; in $\mathrm{C}=500 \mu \mathrm{m}$; and in $\mathrm{D}=20 \mu \mathrm{m}$.

Spermatocytes and sperm cells were first observed at 140

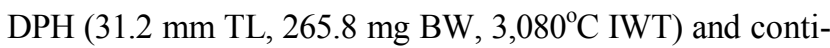
nued to mature through $170 \mathrm{DPH}$ (Fig. 4D). These observations indicate that the Korean rose bitterling belongs to the differentiated type of gonochoristic teleosts (Fig. 5).

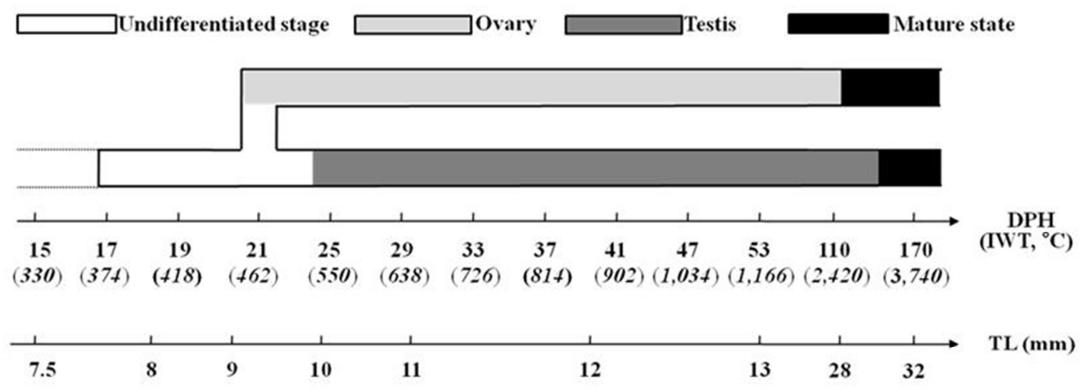

Fig. 5. Diagram of the gonadal development and differentiation of the Korean rose bitterling, Rhodeus uyekii in relation to DPH, TL, and IWT. 


\section{DISCUSSION}

The present study shows that although the TL of the Korean rose bitterling, Rhodeus uyekii, increased continuously post-hatching, the BW decreased somewhat until yolk absorption was complete and feeding began (at 21 DPH). This likely reflects the dependence of the metabolism on energy from the yolk rather than the intake of exogenous food.

The sex differentiation of Teleostei varies and can show irregular features, and many gonochoric fishes, including some hermaphroditic fishes, easily change sex (Devlin \& Nagahama, 2002). In aquaculture, this has been used to produce monosexual populations with improved economics. Thus, we need to fundamentally understand the sex differentiation and sex change of fishes (Park et al., 2004). Here, the sex differentiation of the Korean rose bitterling was analyzed with respect to TL and BW at various DPH. Result of gonadogenesis and sex differentiation in European eel, Anguilla anguilla and bagrid catfish, Pseudobagrus fulvidraco. These results relatively correct better than previous studies based on simply DPH (Colombo \& Grandi, 1996; Park et al., 2004). Moreover, as include the integral water temperature for check factor in this study, it will be more correctly standard than previous studies.

PGCs appear at different times and in different areas across species. Those of the tilapia, Tilapia zillii, appear at hatching; those of the rainbow trout, Salmo gairdneri, are first seen at 36 DPH under the mesonephric duct; those of the ussurian bullhead, Leiocassis ussuriensis, and black bullhead, P. koreanus, appear at 1 DPH; those of the Korean bullhead appear at $3 \mathrm{DPH}$; and those of the Chinese minnow, Moroco oxycephalus, appear at $8 \mathrm{DPH}$ under the air bladder mesentery (Yoshikawa \& Oguri, 1978; Takashima et al., 1980; Park et al., 1998, 2001, 2004, 2008). The present study shows that the PGCs of the Korean rose bitterling first appear at $17 \mathrm{DPH}$ under the air bladder mesentery, and formation genital ridge thus confirmed early gonad.

Undifferentiated gonads of fish during gonadal differentiation in the ovary or testis differentiation into different duct can be determined by forming patterns. Ovarian differentiation in the Korean rose bitterling began at 21 DPH (9.2 $\pm 0.14 \mathrm{~mm}$ TL, $4.8 \pm 0.07 \mathrm{mg} \mathrm{BW}, 462^{\circ} \mathrm{C}$ IWT), as indicated by the appearance of meiotic prophase oocytes. The timing of sex differentiation differs by species, beginning at $40 \mathrm{DPH}\left(326^{\circ} \mathrm{C}\right.$ IWT $)$ in the cherry salmon, Oncorhynchus masou, but at $\left(270^{\circ} \mathrm{C}\right.$ IWT) in the coho salmon, O. kisutch (Pifferrer \& Donaldson, 1989; Park et al., 1997). However, there seems to be some consistency in that the sex differentiation of various fish species begins at the time the yolk sac is completely absorbed and the first feeding occurs, such as in the rainbow trout, the cherry salmon (40 DPH) (Park et al., 1997; Van den Hurk \& Solf, 1981), and the Korean rose bitterling (21 DPH; this work).

The sex differentiation of teleosts can be grouped at the level of species or family, with the process occurring at 10 40 DPH in cichlids, 10 30 DPH in Cyprinodontids, and 3 40 DPH in Anabantids (Yamazaki, 1976; Shelton \& Jensen, 1979; Pandian \& Sheela, 1995). The sex differentiation of the Ussurian bullhead occurs at 15 20 DPH and that of the Korean bullhead occurs in a similar range of 12-20 DPH, while those of the mandarin fish, Siniperca scherzeri, and cherry salmon begin somewhat later, at 40 DPH (Park et al., 1997, 2001, 2004). The present study shows that the sex differentiation of the Korean rose bitterling occurs at 21 25 DPH, with ovaries first seen at $21 \mathrm{DPH}$ and testes observed at $25 \mathrm{DPH}$. In some fishes, such as the ocean perch, Diterma temmincki, testicular differentiation is seen first; however, most fish show initial differentiation of the ovary (Takashima et al., 1980; Lee \& Lee, 1996; Park et al., 2004), as observed here for the Korean rose bitterling.

Ovary formation of teleost are two main forms. The entovarian sac forms at the center of the ovarian cavity, while the parovarian sac forms on the edge of ovary (Lee 
\& Lee, 1996). The sweet fish, Plecoglossus altivelis, and the threespine stickleback, Gasterosteus aculeatus, reportedly form parovarian sacs (Bang et al., 2000), while the white spotted char, Salvelinus leucomaenis, the rainbow trout, and the ussurian bullhead reportedly form entovarian sacs. The present study shows that the Korean rose bitterling forms its sacs in the middle of the ovary pattern, indicating that this species forms entovarian sacs (Takashima et al., 1980; Park et al., 2001).

The observation that the Korean rose bitterling began ovarian differentiation at $21 \mathrm{DPH}$ and testicular differentiation at $25 \mathrm{DPH}$ indicates that this species exhibits gonochorism. In this, the Korean rose bitterling resembles the rainbow trout, the chum salmon, O. keta, the medaka, Oryzias latipes, the ussurian bullhead, the Chinese minnow, and the ocean perch (Robertson, 1953; Tuzuki et al., 1966; Yoshikawa \& Oguri, 1978; Takashima et al., 1980; Lee \& Lee, 1996; Park et al., 1998, 2001).

The Korean rose bitterling is endemic species to Korea and the importance in the resources enforcement has been emerged (Jeon, 1982). Therefore, it is important that we understand the timing of sex differentiation timing and the sex ratio in this species. Future studies should focus on tracking the differentiation and development of the gonad in the Korean rose bitterling to see how the sex ratio and timing of sex differentiation can be altered by artificial factors (e.g., hormones and environmental factors). The results of the present study could be utilized as fundamental data for the resources proliferation and the ecological changes in this species.

\section{ACKNOWLEDGEMENTS}

This work was supported by a grant from the National Institute of Fisheries Science (R2016010). The comments of anonymous reviewers greatly improved the quality of the manuscript. We declare that all experiments in this study complied with the current laws of Korea (Ordinance of Agriculture, Food and Fisheries, No. 1, Regarding Experimental Animals, No. 9,932).

\section{REFERENCES}

An CH (1995) Reproductive cycle of the spring-spawning bitterling, Rhodeus uyekii (Pisces: Cyprinidae). Kor J Ichthyol 7:33-42.

Bang IC, Park SY, Lee YA, Lee CH, Kim SY, Kim KK (2000) Early gonadogenesis and sex differentiation in sweet fish, Plecoglossus altivelis. J Aquacult 13:215-222.

Baroiller JF, Guiguen Y, Fostier A (1999) Endocrine and environmental aspects of sex differentiation in fish. Cell Mol Life Sci 55:910-931.

Chae BS (2001) Elongation of the ovipositor in Korean rose bitterling, Rhodeus uyekii (Pisces: Cyprinidae). Kor J Ichthyol 13:111-116.

Colombo G, Grandi G (1996) Histological study of the development and sex differentiation of the gonad in the European eel. J Fish Biol 48:493-512.

Devlin RH, Nagahama Y (2002) Sex determination and sex differentiation in fish: An overview of genetic, physiological, and environmental influences. Aquaculture 208:191-364.

Gray AM, Metcalfe CD (1997) Induction of testis-ova in Japanese medaka (Oryzias latipes) exposed to $p$-nonylphenol. Environ Toxic Chem 16:1082-1086.

Jeon SR (1982) Studies on the distribution of the Acheilognathid fishes (Cyprinidae) from Korea. Ann Rep Biol Res 3:33-47.

Kang EJ, Kim CH, Park I-S, Yang H, Cho YC (2006) Early developmental characteristics of induced hybrids between Rhodeus uyekii and R. notatus (Pisces: Cyprinidae). Kor J Ichthyol 18:339-346.

Kang EJ, Kim E-M, Kim YJ, Lim SG, Sim DS, Kim Y-H, Park I-S (2005) Effect of lidocaine hydrochloride and clove oil as an anaesthetic on Korean rose bitterling, Rhodeus uyekii and oily bitterling, Acheilgnathus koreensis. J Aquacult 18:272-279. 
IB Goo, JE Kim, MH Kim, H-S Choi, HJ Kong, JH Lee, I-S Park

Kim B-S, Kang EJ, Jang H, Park I-S (2012) Morphometric traits and cytogenetic analysis in induced cross and reciprocal hybrid between Rhodeus uyekii and R. notatus. Kor J Ichthyol 24:151-159.

Kim B-S, Lim S-G, Gil HW, Park I-S (2011) Temperaturedependent index of mitotic interval $\left(\tau_{0}\right)$ for chromosome manipulation in Korean rose bitterling, Rhodeus uyekii. J Fish Aquat Sci 14:429-434.

Kim IJ (1997) A osteological study of Rhodeus uyekii. Kor J Ichthyol 9:130-140.

Kim YU, Han KH (1990) Early life history of the Korean bitterling, Rhodeus uyekii (Cyprinidae), reared in the laboratory. Kor J Ichthyol 2:159-168.

Lee JS, Lee YD (1996). Early gonadogenesis and sex differentiation in the viviparous teleost, Ditrema temmincki. J Korean Fish Soc 29:35-43.

Nakamura M (1969) Cyprinid Fishes of Japan, Studies on the Life History of Cyprinid Fhised of Japan. Res Ins Nat Res, Tokyo, pp 5-99.

Pandian TJ, Sheela SG (1995) Hormonal induction of sex reversal in fish. Aquaculture 138:1-22.

Park I-S, Kim JH, Bang IC, Kim DS (1998) Histological study of the early gonadal development and sexual differentiation in Rhynchocypris oxycephalus. Dev Reprod 2:69-74.

Park I-S, Kim JH, Bang IC, Kim DS (2004) Sex differentiation and hormomal sex reversal in the bagrid catfish, Pseudobagrus fulvidraco (Richardson). Aquaculture 232: 183-193.

Park I-S, Lee YD, Chung EY (1997) Gonadal sex differentiation in cherry salmon, Oncorhynchus masou. Bull Mar Res Inst Cheju Nat Univ 21:1-9.

Park JS, Lee WK, Park CK, Heo SJ, Ki SW, Choi NH (2008) Gonadal development and sex differentiation of a Korean endemic species, black bullhead Pseudobagrus koreanus. Dev Reprod 12:215-220.

Park KN, Kim CH (1990) Egg and larval development and seasonal sex ratio of Korean endemic fresh water fish, Rhodeus uyekii. J Natural Sci Res Ins 3:29-33.

Park SY, Lee YA, Choi KC, Kang EJ, Bang IC (2001) Early gonadogenesis and sex differentiation in the bagrid catfish, Leiocassis ussuriensis. Kor J Ichthyol 13: 248-253.

Pifferrer F, Donaldson EM (1989) Gonadal differentiation in coho salmon, Oncorhynchus kisutch, after a single treatment with androgen at different stages during ontogenesis. Aquaculture 77:251-262.

Robertson JG (1953) Sex differentiation in the Pacific salmon, Oncorhynchus keta (Walbaum). Can J Zool 31:73-79.

Shelton WL, Jensen GL (1979) Production of reproductively limited grass carp for biological control of aquatic weeds. Water Res Res Inst Auburn Univ 39:1-174.

Takashima F, Patino R, Nomura M (1980) Histological studies on the sex differentiation in rainbow trout. Bull Jap Soc Sci Fish 46:1317-1322.

Tuzuki E, Egami N, Hyodo Y (1966) Multiplication and sex-differentiation of germ cells during development in the medaka, Oryzias latipes. Jap J Ichthyol 13:176-182.

Uchida K (1939) The fished of Tyosen. Part 1. Nematognathi and eventognathi. Bull Fish Exp State 6, pp 88-177.

Van den Hurk R, Slof GA (1981) A morphological and experimental study of gonadal sex differentiation in the rainbow trout, Salmo gairdneri. Cell Tissue Res 218: 487-497.

Yamamoto T (1969) Sex differentiation. In: Hoar WS, Randall DJ, Donaldson EM (Eds), Fish Physiology, Vol. III, Academic Press, New York, pp. 117-158.

Yamazaki F (1976) Application of hormone in fish culture. J Fish Res Board Can 33:948-985.

Yoshikawa H, Oguri M (1978) Effect of steroid hormones on the sex differentiation in a cichlid fish Tilapia zillii. Nip Sui Gakkai 44:1093-1098. 